\title{
UNIVERSITY-INDUSTRY COLLABORATIVE PROJECTS: ANALYSIS AND PROPOSAL OF
} MANAGEMENT PRACTICES

\begin{abstract}
This study aims to identify good managerial practices on university-industry collaborative projects. The literature review was based on studies that analyzed management of collaborative projects and included authors such as Davenport et al. (1998), Moro-Valentin et al (2003), Barnes et al (2006), and Albertin and Amaral (2010). An empirical research was carried out by studying multiple cases of University-Industry collaborative projects in Brazil. Project managers, entrepreneurs and researchers involved in such projects answered a semi-structured interview that helped understand how they are managed. Results showed that best practices already suggested by literature are implemented, as well as new practices that are positively associated with project performance. Setting clear and realistic goals, defining clear responsibilities, writing clear agreements, and communicating effectively were practices found in literature. New practices consisted of maintaining close contact with partners, systematically recording information on the project, conducting startup meetings to formalize and disseminate information about the project, holding periodical meetings to monitor the project, using software or a project management platform, and clearly defining processes. A guide presenting ten best practices for managing University-Industry collaborative projects was created based on the results found in this study.
\end{abstract}

Keywords: Project Management. University-Industry Collaboration. Inter-organizational Relations. Good Management Practices.

\section{PROJETOS COLABORATIVOS ENTRE UNIVERSIDADE E EMPRESA: ANÁLISE E PROPOSTA DE PRÁTICAS GERENCIAIS}

\section{RESUMO}

Este estudo tem como objetivo identificar boas práticas de gerenciamento em projetos colaborativos entre universidades e empresas. A revisão da literatura foi baseada em estudos que analisaram tais projetos, como Davenport et al (1998), Moro-Valentin et al (2003), Barnes et al (2006) e Albertin e Amaral (2010). A pesquisa empírica foi conduzida por meio de estudos de caso múltiplos de projetos entre universidades e empresas brasileiras. Entrevistas semiestruturadas foram realizadas com gerentes de projeto, empreendedores e pesquisadores envolvidos, a fim de propiciar um entendimento sobre como são gerenciados. Projetos considerados de sucesso foram comparados com projetos considerados problemáticos. Os resultados confirmaram boas práticas já mencionadas na literatura, bem como práticas não mencionadas. Estabelecer objetivos claros e realistas, definir responsabilidades de forma clara, firmar contratos claros e comunicar-se efetivamente foram práticas encontradas na literatura, enquanto estabelecer contato pessoal entre os parceiros, registrar as informações do projeto de maneira sistemática, conduzir reuniões de abertura, estabelecer reuniões periódicas, utilizar um software para gestão do projeto e definir os processos da universidade claramente estão entre as práticas mencionadas pelos participantes, mas não mencionadas na literatura abordada. A partir destes resultados, foi proposto um guia contendo dez práticas recomendadas para condução de projetos colaborativos entre universidades e empresas.

Palavras-chave: Gerenciamento de Projetos. Colaboração Universidade-Empresa. Relações Interorganizacionais. Boas Práticas Gestão.

\footnotetext{
${ }^{1}$ Master in Business Administration from University of Santa Cruz do Sul - UNISC. Project`s Manager at Feevale University. Brazil. E-mail: anak@feevale.br

${ }^{2}$ Doctor in Business Administration from Universidade do Vale do Rio dos Sinos - UNISINOS and Economía de L'Company by University of the Balearic Islands - UIB, Spain. Professor in Creative Industries at Feevale University. Brzsil. E-mail: serje@feevale.br

${ }^{3}$ Business Administration degree from Feevale University. Brazil. E-mail: dalri.rafael@gmail.com
} 


\section{INTRODUCTION}

Traditional sources of competitive advantage such as capital, physical location, and technology or raw material availability are in frank regression, as they have become more easily accessed by organizations (Prahalad \& Krishnan 2008). The increased competition, as well as the complexity of the organizations' internal and external environments, have induced practioners and researchers to concentrate their efforts on developing managerial practices that potentialize innovation (Nagano, Stefanovitz \& Vick, 2014). The exploration of external sources of knowledge, while consolidates firms' inter-organizational relations (Castells 1999; Gulati, Lavie \& Madhavan, 2011), is among these managerial practices (Bellucci \& Pennacchio, 2015).

Corporations currently need to focus on core competencies and rely on partners to complement each other (Hamel 1991; Johansson \& Kurkkio 2007). They can access resources and aptitudes of external organizations through alliances and collaborative agreements (Lynskey 1999; Hagedoorn, Link \& Vonortas, 2000), thus developing and promoting new skills (Powel et al 1996), and generating higher competitiveness (Powell et al 1996; Pittaway et al 2004; Soda, 2011). Collaborative strategies can be directed to academic partners to enhance innovative performance (Levine \& Prietula 2013; Brocke \& Lippe 2015). It provides access to knowledge and technologies on a larger scale than that possible through internal development (Salter \& Martin 2001; Etzkowitz 2009).

University-Industry collaboration is considered to enhance the flow of tacit and formal knowledge related to technology in all economic sectors (Ankrah \& Al-Tabbaa, 2015). This type of relationship, however, faces many challenges regarding managerial practices, due to its high uncertainty and risks, individuality of the persons involved in the project, heterogeneity of the partners and the significant pressure to achieve creativity and produce innovation (Brocke \& Lippe, 2015).

In order to successfully manage projects in such relationships, organizations need to be acquainted with practices that may be of potential benefit Lagzian, Abrizah \& Wee (2013). Once these practices are identified, explored and used, the probability of success is higher, since they may be applied to support and measure the project development (Hwang \& Lim, 2013). It's also important to understand that the concept of project success is subjective (Garg \& Agarwal, 2014; Rashvand \& Zaimi, 2014).

However, potential benefits of collaborative processes are often not perceived in practice (Barnes,
Pashby \& Gibbons, 2006). This is mainly because successful collaborations between two or more organizations require considerable management effort. Collaborative projects between universities and corporations (U-I) pose special challenges due to the high degree of uncertainty and risks (Barnes, Pashby \& Gibbons, 2006) which demand changes and adaptations by management practices when compared to traditional projects (Brocke \& Lippe 2015). It is important to identify how to manage these projects in order to achieve desired results.

Several approaches to project management best practices are available, such as the Project Management Book of Knowledge (PMBOK), ISO 10006: 1997, Quality management-guidelines for quality in project management, PRINCB2 тм: Projects in the Control Environment and International Project Management Association (IPMA®). Among these, the PMBOK is the most widely used. In PMBOK, however, practices are universal and do not consider the singularities of UI collaborative projects where the institutions involved are fundamentally distinct in terms of culture and modus operandi (Plonski 1994). One of the cultural conflicts usually stems from the fact that partners do not have comprehensive managerial ability to complete a project individually (Davenport, Davies \& Grimes, 1998; Ahuja, 2000). Several authors suggest additional empirical research on this topic (i.e.: Barnes et al 2006; Davenport et al 1998; Moro-Valentin et al 2003; Albertin \& Amaral 2010).

Previous studies about this subject concentrated on the firms' view of critical success factors (CSFs) or, separately, the view of the research organization. Elements related to the context of the relationship, such as the partner's experience in collaboration, staff quality, etc., or universal CSFs, such as leadership and flexibility were also investigated. Costa, Porto and Feldhaus (2010), for example, presented important contributions about the understanding of U-I collaborative projects, but their study was relative to the challenges involved in the initial concept of collaboration among the partners. An integrated perspective, considering the researcher, the manager and the organizations' view, focusing specifically on management practices, was not found in the literature. Based on these previous studies, the present work intends to address this gap, as it aims to identify good managerial practices on universityindustry collaborative projects.

Therefore, the purpose of this study is to empirically identify best management practices in $\mathrm{U}$ I collaborative projects and to present a guide for these practices. In order to accomplish its purpose, 
the next section of this paper presents a brief literature review on management practices for U-I collaborative projects. Methods are then described, specifying which steps were taken for data collection and analysis. Result analysis, identification of best practices and a best practices guide follow. Finally, authors present the conclusions for this study, as well as its contributions and limitations, and suggestions for further research.

\section{PRACTICES ON U-I COLLABORATIVE PROJECTS}

Jones and Lichtenstein (2008) define collaborative projects as those in which several organizations work together in a shared activity for a limited period. They point out that this type of design is being increasingly used to coordinate the development of complex products and services in uncertain and competitive environments, as is the case of projects developed between universities and corporations. Davenport et al (1998), Moro-Valentin et al (2003), Barnes et al (2006) and Albertin and Amaral (2010), among others, specifically studied management practices for U-I collaborative projects.

Davenport et al (1998) studied a program from the New Zealand Government entitled Business Growth Programme (TBG), which sponsors collaborative research for innovation. Each project in this program is developed by a business organization and a research institution. Five management practices were identified and considered vital for most managers: 1) the correct selection of the collaborative partner; 2) clear understanding of responsibilities; 3) establishment of common tasks and goals without hidden agendas; 4) mutual respect and trust between partners, and 5) top management commitment in all phases.

Moro-Valentin et al (2003) indicated some factors that could lead to the success of U-I partnerships. Their study, conducted in Spain, presented practical recommendations to operate and manage collaborative projects according to two dimensions: contextual and organizational. Contextual factors include partners' features and their governance-related issues such as previous connections, reputation, and proximity between partners. Organizational factors comprise partners' behaviors and their influence on other partners, such as commitment, communication, trust, conflict, and dependence. They found nine relevant best practices for managing U-I collaborative projects: four relating to a contextual dimension, and five relating to an organizational dimension. Davenport et al (1998) confirmed certain practices identified by Moro-Valentin et al (2003), but new factors were also found, such as communication and conflict resolution.

Table 1 - Project management best practices

Source: created by the authors (2015) based on Moro-Valentin et al (2003).

\begin{tabular}{|l|l|}
\hline Factors & \multicolumn{1}{c|}{ Identified best practices } \\
\hline \multirow{4}{*}{ Contextual } & Previous cooperative experiences \\
\cline { 2 - 2 } & Partner Reputation \\
\cline { 2 - 3 } & Clearly defined goals \\
\cline { 2 - 2 } & $\begin{array}{l}\text { Institutionalization of the relation (rules, policies, procedures, legal issues, and well- } \\
\text { defined administrative procedures) }\end{array}$ \\
\hline \multirow{4}{*}{ Organizational } & Commitment \\
\cline { 2 - 2 } & Communication \\
\cline { 2 - 2 } & High level of reliability \\
\cline { 2 - 3 } & $\begin{array}{l}\text { Conflict resolution } \\
\text { Dependency between partners (in terms of financial and intellectual resources, for } \\
\text { example) }\end{array}$ \\
\hline
\end{tabular}

Barnes et al (2006) selected six projects from the Warwick Manufacturing Group Program (WMG) that has been investigating the collaboration between universities and industries in the UK since its founding in 1980. The aim of their study was to test the influence of success factors identified in literature over the outcome of each project. Five among the six case studies were part of a large collaborative program involving the WMG and about 25 automotive corporations. In each case, interviewees were members of the collaborating corporations, were academic researchers and, when applicable, were technical personnel directly involved in the projects. Documents such as project meeting notes, corporation records, and direct observation of project status meetings complemented data. Table 2 presents the critical success factors found in these projects. 
Table 2 - Critical success factors (CSFs) identified by Barnes et al (2006)

\begin{tabular}{|c|c|c|}
\hline Key themes & Sub-theme & Critical factors identified \\
\hline \multicolumn{2}{|c|}{ Issues of cultural differences } & $\begin{array}{l}\text { - Divergence in priorities/deadlines; } \\
\text { - Public domain publication; } \\
\text { - Lack of understanding about business requirements; } \\
\text { - Lack of flexibility (corporation); } \\
\text { - Rights of intellectual property and confidentiality. }\end{array}$ \\
\hline \multirow[t]{2}{*}{ Partners Issues } & Partner Evaluation & $\begin{array}{l}\text {-Cultural compatibility/operating mode; } \\
\text { - Mutual understanding; } \\
\text { - Expertise and complementary strengths; } \\
\text { - Past collaboration partners; } \\
\text { - High quality staff; } \\
\text { - Strategic importance; } \\
\text { - Complementary goals; } \\
\text { - No hidden agendas; } \\
\text { - Collaborative experience. }\end{array}$ \\
\hline & Project Manager & $\begin{array}{l}\text { - Trained in project management; } \\
\text { - Diplomacy; } \\
\text { - Experience in collaboration; } \\
\text { - Multifunctional experience. }\end{array}$ \\
\hline \multirow[t]{3}{*}{$\begin{array}{l}\text { Project preparation } \\
\text { and execution }\end{array}$} & Project Management & $\begin{array}{l}\text { - Clearly defined goals; } \\
\text { - Clearly defined responsibilities; } \\
\text { - Mutually agreed project plans; } \\
\text { - Realistic goals; } \\
\text { - Adequate resources; } \\
\text { - Defined project milestones; } \\
\text { - Simple collaborative agreements; } \\
\text { - Regular progress monitoring; } \\
\text { - Effective communication; } \\
\text { - Insured employee deliveries. }\end{array}$ \\
\hline & Equality Assurance & $\begin{array}{l}\text { - Mutual benefit; } \\
\text { - Equal power/dependence; } \\
\text { - Equality of contribution. }\end{array}$ \\
\hline & External Influences & $\begin{array}{l}\text { - Market needs; } \\
\text { - Corporate stability. }\end{array}$ \\
\hline \multicolumn{2}{|c|}{ Universal Success Factors } & $\begin{array}{l}\text { - Mutual trust; } \\
\text { - Commitment; } \\
\text { - Flexibility; } \\
\text { - Learning; } \\
\text { - Staff continuity; } \\
\text { - Good personal relationships/team work; } \\
\text { - Collaboration; } \\
\text { - Leadership. }\end{array}$ \\
\hline
\end{tabular}

Source: created by the authors based on Barnes et al (2006).

Barnes et al (2006) identified a greater number of best practices (or critical factors, as they called) then previous studies. This was probably due to the establishment of a larger structure of analysis, considering cultural issues, partner issues, the preparation and execution of the project, and universal success factors. This structure offered a wider insight into the factors that require special attention to successfully manage U-I collaborative projects. For the purposes of this study, the practices mentioned under the sub-theme "Project Management" are of special interest, and will be used in the analysis.

Based on Barnes et al (2006), Albertin and Amaral (2010) analyzed two projects from a research program at the University of São Paulo (USP). In project A, four critical factors predicted in the literature were considered present and 
influential: 1) complementary expertise;2) complementary objectives;3) understanding university-business imperatives; and, 4) equality in contributions. In addition, three new factors were also identified as present and influential: 1) having a full-time project manager with technical knowledge; 2) clear definition of requirements early in the project and their maintenance over time; and 3) having a development specialist in the project area.

In project $B$, 13out of 40 critical success factors were studied, and considered present and influential in the opinion of participants such as:1) known and accepted goals, 2) realistic goals, 3) clearly defined responsibilities, 4) mutually agreed upon project plans, 5)adequate resources,6) regular progress monitoring,7) commitment, 8) staff continuity, 9) good personal relations between partners, 10) collaboration champion, 11) negotiation, 12) strategic relevance, and 13) flexibility-business. In addition, there was a critical success factor considered absent and influential: critical success factors learning and use. Researches did not observe different critical success factors in Project B due to shorter duration and easy implementation.

Table 3 presents a compilation of the common best practices found in the abovementioned studies.

Table 3 - Common best practices of U-I project management

\begin{tabular}{|c|c|c|c|c|}
\hline Practices & 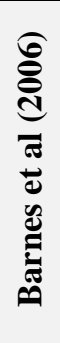 & 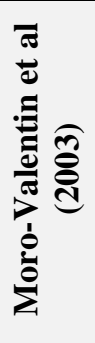 & 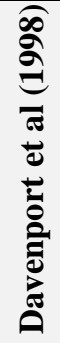 & 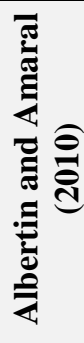 \\
\hline Clearly defined objectives & & & & \\
\hline Clearly defined responsibilities & & & & \\
\hline Mutually agreed project plans & & & & \\
\hline Realistic objectives & & & & \\
\hline Adequate resources & & & & \\
\hline Clearly defined project milestones & & & & \\
\hline Simple collaborative agreements & & & & \\
\hline Regular progress monitoring & & & & \\
\hline Effective communication & & & & \\
\hline Insured employee deliveries & & & & \\
\hline Mutual benefits & & & & \\
\hline Equal power/dependence & & & & \\
\hline Equality in contribution & & & & \\
\hline Market needs & & & & \\
\hline Corporate stability & & & & \\
\hline Conflict resolution & & & & \\
\hline
\end{tabular}

Source: created by the authors based on Davenport et al (1998), Moro-Valentin et al (2003), Barnes et al (2006), and Albertin and Amaral (2010).

The methods that guided this research are presented next.

\section{METHOD}

Assuming a functionalist and interpretative paradigms perspective (Burrel \& Morgan, 1998), a qualitative research was carried out to attend the research's objectives. The units of analysis were completed or almost completed U-I collaborative projects that had a coordinator at the corporation and 
a research engineer at the university. Two successful and two unsuccessful projects were selected to determine more clearly which practices were related - or not - to success. Project performance was attributed from the perspective of managers -either the managers of Technological Innovation Centers or the person responsible for managing projects at the universities.

Four collaborative research projects developed by three universities in collaboration with four different corporations were selected. These universities were selected by accessibility, but they also are among the biggest universities in the state of Rio Grande do Sul, Brazil. The excellency of its collaborative research projects is recognized by governmental agencies that support this kind of project, such as FINEP, CNPq, BNDES and the Secretaria de Desenvolvimento Tecnológico e Inovação do Estado do RS. The managers in these universities have a large experience in project management (see Table 4).
Project success, however central this concept is to project management (Heravi \& Ilbeigi, 2012), still lacks consensus on its definition. Ejaz et al. (2013) proposed two main success elements in a project: its management and its product. Management refers mainly to its completion within the initial parameters of time, cost, quality and satisfaction of its stakeholders. Therefore, the following criteria was used to evaluate the project as successful or unsuccessful: 1) timely project completion within the predicted dates, 2) project implementation without deviation within the existing processes and, 3) feedback from those involved during the project or after its completion.

Based on these definitions, the research engineer, and the managers in charge of the projects at the university and at the corporations answered an in-depth interview. Projects A and B were considered successfully managed, and projects $\mathrm{C}$ and D were considered unsuccessfully managed. As the identity of the participants was preserved, Table 4 presents codes that identify their answers.

Table 4 - Identification of projects and participants

\begin{tabular}{|c|c|c|c|c|c|}
\hline \multicolumn{3}{|c|}{ Projects } & \multicolumn{3}{|c|}{ Interviewees } \\
\hline Id & $\begin{array}{c}\text { Participant } \\
\text { University }\end{array}$ & Performance & Project Manager & Researcher & Businessman \\
\hline A & U1 & Successful & $\begin{array}{l}\text { PM1: bachelor degree } \\
\text { in Law. Eight years as } \\
\text { PM. }\end{array}$ & $\begin{array}{l}\text { R1: PhD in } \\
\text { Information } \\
\text { Technology (IT). } \\
\text { Two years in the } \\
\text { current project. } \\
\text { Also has previous } \\
\text { experience in U-I } \\
\text { projects. }\end{array}$ & $\begin{array}{l}\text { B1: Specialist in IT. } \\
\text { Responsible for PM } \\
\text { in the firm. } \\
\text { Participated in the } \\
\text { current project since } \\
\text { its beginning. }\end{array}$ \\
\hline B & U3 & Successful & $\begin{array}{l}\mathrm{PM} 2: \mathrm{PhD} \text { in Business. } \\
\text { Four years as PM } \\
\text { University Advisor. }\end{array}$ & $\begin{array}{l}\mathrm{R} 2: \mathrm{PhD} \text { in } \\
\text { Chemistry. In the } \\
\text { current project } \\
\text { since its beginning } \\
\text { (3 years). }\end{array}$ & $\begin{array}{l}\text { B2: bachelor degree } \\
\text { in Mechanics. Is in } \\
\text { this project since the } \\
\text { beginning and has } \\
\text { participated in a } \\
\text { dozen previous U-I } \\
\text { projects. }\end{array}$ \\
\hline $\mathrm{C}$ & U2 & Unsuccessful & $\begin{array}{l}\text { PM3: bachelor degree } \\
\text { in Public Relations. } \\
\text { Five years as PM. }\end{array}$ & $\begin{array}{l}\text { R3: PhD in } \\
\text { Electronics. In the } \\
\text { current project } \\
\text { since its beginning } \\
\text { (3 years). }\end{array}$ & $\begin{array}{l}\text { B3: Electrical } \\
\text { technician. More } \\
\text { than } 10 \text { years as U-I } \\
\text { PM. }\end{array}$ \\
\hline $\mathrm{D}$ & $\mathrm{U} 2$ & Unsuccessful & $\begin{array}{l}\text { PM4: Specialist in } \\
\text { Business. More than } 20 \\
\text { years as PM. }\end{array}$ & $\begin{array}{l}\text { R4: } \mathrm{PhD} \text { in } \\
\text { Biology. In the } \\
\text { current project } \\
\text { since its beginning } \\
\text { ( } 2 \text { years). }\end{array}$ & $\begin{array}{l}\text { B4: Environmental } \\
\text { technician. No } \\
\text { previous experience } \\
\text { in U-I projects. }\end{array}$ \\
\hline
\end{tabular}

Source: elaborated by the authors. 
Two steps were followed in writing the interview questions. First, the list of best practices identified in the literature (Table 3 ) was sent by email and presented over a telephone call for validation by eight experts. Researched evaluated and analyzed the experts' contributions made by the experts, which resulted in a reduction of the best practices list from fifteen to nine items. Table 5 presents the final list of best practices used in this research, which made up the basis for the interview questions. An additional group of three experts further validated the interview questions. They understood that the questions were adequate and would provide the information needed to achieve the research objectives.

Table 5 - Management practices used in interview questions

\begin{tabular}{|c|c|}
\hline Management practices & Authors \\
\hline Adopt clear and realistic goals & $\begin{array}{l}\text { Kerzner (2006) } \\
\text { Barnes, Pashby and Gibbons (2006) } \\
\text { Moro-Valentin, Montoro-Sanchez and Guerra-Martin (2003) } \\
\text { Albertin and Amaral (2010) }\end{array}$ \\
\hline Define responsibilities clearly & $\begin{array}{l}\text { Barnes, Pashby and Gibbons (2006) } \\
\text { Moro-Valentin, Montoro-Sanchez and Guerra-Martin (2003) } \\
\text { Albertin and Amaral (2010) } \\
\text { Davenport, Davies and Grimes (1998) }\end{array}$ \\
\hline Adopt formal contractual agreements & $\begin{array}{l}\text { Kerzner (2006) } \\
\text { Barnes, Pashby and Gibbons (2006) } \\
\text { Moro-Valentin, Montoro-Sanchez and Guerra-Martin (2003) } \\
\text { Albertin and Amaral (2010) }\end{array}$ \\
\hline Clearly defined project milestones & $\begin{array}{l}\text { Kerzner (2006) } \\
\text { PMBOK (2012) } \\
\text { Barnes, Pashby and Gibbons (2006) }\end{array}$ \\
\hline $\begin{array}{l}\text { Adequate resources (human, material, and } \\
\text { financial) }\end{array}$ & $\begin{array}{l}\text { Kerzner (2006) } \\
\text { Albertin and Amaral (2010) } \\
\text { Barnes, Pashby and Gibbons (2006) }\end{array}$ \\
\hline Simple collaborative agreement & $\begin{array}{l}\text { Barnes, Pashby and Gibbons (2006) } \\
\text { Kerzner (2006) }\end{array}$ \\
\hline $\begin{array}{l}\text { Regular progress monitoring (hold periodical } \\
\text { meetings) }\end{array}$ & $\begin{array}{l}\text { Kerzner (2006) } \\
\text { Albertin and Amaral (2010) } \\
\text { Barnes, Pashby and Gibbons (2006) }\end{array}$ \\
\hline Effective communication & $\begin{array}{l}\text { Barnes, Pashby and Gibbons (2006) } \\
\text { Moro-Valentin, Montoro-Sanchez and Guerra-Martin (2003) } \\
\text { Albertin and Amaral (2010) } \\
\text { Van de Ven and Walker (1984) }\end{array}$ \\
\hline Conflict resolution & $\begin{array}{l}\text { Thamhain and Willemon (2974) } \\
\text { Kerzner (2006) } \\
\text { Moro-Valentin, Montoro-Sanchez and Guerra-Martin (2003) }\end{array}$ \\
\hline
\end{tabular}

Source: created by the authors (2015).

In addition to these practices, questions related to the evaluation of project results and management, as well as suggestions on what could have been done differently regarding management, were included in the interview questions to include an additional perspective on project development.

Next, individuals with roles similar to those participating in this research answered pilot interviews: an entrepreneur, a researcher and a project manager at a university. These pilot interviews were conducted based on the same project that was considered successful by the responsible university. Pilot-data analysis and validation indicated that no changes were needed in the interview questions, except that it would be appropriate to explore the questions more deeply, also requesting examples from the participants where needed. A particular practice should meet one of the following criteria in order to be considered "good" for this study: 1) present in two successful projects, and absent in one or none of the unsuccessful projects; 2) identified as present in one successful project, and absent in two of the unsuccessful projects.

Participants answered the interviews from December 2014 to March 2015. Twelve interviews were 
realized, totaling nine hours of recording, averaging 45 minutes per interview. From this time, 15 minutes were devoted to informal conversations in each interview conducted to better understand the contextual environment of the projects. The answers were transcribed, resulting in 87 pages of transcriptions, and analyzed based on content analysis (Bardin 2011), in three steps. In the first step, the text was pre-analyzed, having been read carefully and repeatedly. It was organized in order to become operational, systematizing its main ideas or topics. In the second step, inferences were established in the text using the categorization based on the literature. The quality of interpretations and inferences could be accessed (Mozzato \& Grzybovski, 2011). Here, categories additional to the literature were discovered in the interviewees' answers, enriching the study. Finally, the third step consisted on the interpretation and analysis of data using inferences, performing a reflexive analysis of the contents. The analysis and interpretation of research results are presented next.

\section{FINDINGS AND INTERPRETATION}

From the collected data, some of the managerial practices identified in the literature were also identified empirically in the interviewees' answers. Practices "clearly defined project milestones", "reports", "manager responsible for the project", "greater interaction between the partners" and "conflict resolution" were each mentioned in only one project or not mentioned at all. As they did not meet the previously established criteria, they were not included in the best practices guide resulting from this research.

Several practices, however, were considered as contributing to project success. From nine best practices listed in literature review and validated by the experts, five were identified as best management practices in the projects that were studied: setting clear and realistic goals; defining responsibilities clearly; adopting formal contractual agreements; communicating effectively, and keeping personal contact. Moreover, four additional good practices emerged from the projects: holding an opening meeting, recording project data, defining clear administrative procedures at the university's project management department, and the using a software or platform for project management. These practices are the focus of this study, because they are more clearly associated with project success. In addition, the practice "periodical meetings" has been highlighted in cases A and B, which were the cases of successful management. For this reason, this practice was included in the guide of best practices. Table 6 presents these practices and the projects where they were identified.

Table 6 - Best practices identified after projects analysis

\begin{tabular}{|l|c|c|c|c|}
\hline & \multicolumn{2}{|c|}{ Successful } & \multicolumn{2}{c|}{ Unsuccessful } \\
\hline \multicolumn{1}{|c|}{ Management Practices } & Project A & Project B & Project C & Project D \\
\hline Defining clear administrative processes (University) & $\mathrm{P}$ & $\mathrm{P}$ & $\mathrm{A}$ & $\mathrm{N} / \mathrm{I}$ \\
\hline Using software or platform for project management & $\mathrm{P}$ & $\mathrm{P}$ & $\mathrm{A}$ & $\mathrm{A}$ \\
\hline Setting clear and realistic goals & $\mathrm{P}$ & $\mathrm{N} / \mathrm{I}$ & $\mathrm{A}$ & $\mathrm{A}$ \\
\hline Defining responsibilities clearly & $\mathrm{P}$ & $\mathrm{P}$ & $\mathrm{N} / \mathrm{I}$ & $\mathrm{A}$ \\
\hline Adopting formal contractual agreements & $\mathrm{P}$ & $\mathrm{P}$ & $\mathrm{N} / \mathrm{I}$ & $\mathrm{A}$ \\
\hline Holding an opening meeting & $\mathrm{P}$ & $\mathrm{P}$ & $\mathrm{N} / \mathrm{I}$ & $\mathrm{A}$ \\
\hline Meeting periodically & $\mathrm{P}$ & $\mathrm{P}$ & $\mathrm{N} / \mathrm{I}$ & $\mathrm{N} / \mathrm{I}$ \\
\hline Maintaining personal contact & $\mathrm{P}$ & $\mathrm{P}$ & $\mathrm{A}$ & $\mathrm{A}$ \\
\hline Communicating effectively & $\mathrm{P}$ & $\mathrm{N} / \mathrm{I}$ & $\mathrm{A}$ & $\mathrm{A}$ \\
\hline Register project data & $\mathrm{P}$ & $\mathrm{N} / \mathrm{I}$ & $\mathrm{A}$ & $\mathrm{A}$ \\
\hline
\end{tabular}

Key: P = Present; A = Absent; N/I = Not Identified.

Source: elaborated by the authors (2015).

Moro-Valentin et al. (2003) had already highlighted the importance of clearly defining administrative processes. This practice was reported several times by participants, indicating that well-defined management processes contribute towards the successful management of collaborative projects. In project $\mathrm{A}, \mathrm{R} 1$ supports this practice by stating that the processes of the university's project management department are so clear and consolidated that there are no doubts regarding project progress. “... The processes of the[university] project management department are very clear. She (the manager at the university) does not need to be constantly called upon. Her activities 
are already very clear for her and all those involved", reports R1.

The use of project management software has not been found in the literature, however, it was mentioned by all participants. The use of a software is important, according to PM1, because "any change, any reassignment that I have, the information will not stay with me (project tmanager). All this information is shared in the system. [Then], at the end of the project, we know why we decided that way" (PM1). At project C's partner corporation, a department dedicated exclusively for project management was created. Besides hiring new employees, the corporation uses a specific software to support project management as B3 reports: "We now have a project management software. So, whatever we are doing we record into this software". The use of a software is important, according to participants, because it enables monitoring and strategically evaluating actions. Another possibility is to write reports based on project data, which optimizes chronology management and promotes dissemination of results among the project team. B3 also suggested that this type of tool could expand to include extranet use, which would also enhance communication between the partners. B4 suggested creating a virtual platform to help record information. An assigned researcher would be responsible for feeding it at least once a week with timely information on the project, describing eventual difficulties and results. This would enable the firm to track project progress in real time, offer suggestions and solutions to the problems that are eventually identified, and evaluate previously obtained results. Regarding the platform or software, B4 made the following contributions: "I think we have to have some way, [like] a platform, something to monitor project execution. To know what has been done, what could not be done, and also record what went right, what went wrong [...] a tool to record the difficulties, even to register what has been learned, to make it possible to estimate the time needed for a new similar project, I do not know if it is offered (at the university) [...] but we need to know this here in real time", says the $\mathrm{B} 4$, referring to a possible platform or software.

The need to set clear and realistic goals and define clear responsibilities was also evident (Davenport et al 1998; Moro-Valentin et al 2003; Barnes et al 2006; Albertin \& Amaral 2010). These two practices were mentioned in the literature and confirmed by participants. The fact that project objectives were jointly defined was identified in researcher R1's account, who highlights that "the objectives were defined together, meaning in an interactive and constructive way in order to reach the goal that the project has today" (R1). In project $\mathrm{D}$, that was the first run by the researcher coordinator, who highlighted an understanding that the project objectives had been achieved: "I think the manager wanted something very commercial [...] so I see that for him the goal was a part of the process, and for me working to achieve the goal was all that was done" (R4). Although the researcher understands that the goals of the project had been achieved, he also acknowledges that the entrepreneur was not content. For B4, "we had a goal that was not very clear, [...] I think that the price of the product was the major flaw". To reinforce the absence of this practice, the entrepreneur believes that "management failed. We should have specified that part of the goal a little better" (B4). Thus, meeting goals from different knowledge areas provides a joint and effective action for the whole group. The need to clearly define project objectives and decide upon the way the project will meet them was enhanced by Kerzner (2006). Barnes et al. (2006) also showed the importance of conducting this process collectively with all participating teams, specially within innovation projects.

In addition, in project $\mathrm{B}$, for example, the responsibilities of those involved in the project were clearly defined from the start because there were people from different areas participating in the team. This practice was also crucial for management success. According to R2, "Every professor has a function and they will take that aspect that corresponds to their methodology". This infers that failing to define responsibilities occurred at the time of designing project D. According to PM4, "given the problem that happened now (the goal has not been achieved in the perspective of the corporation), it seems that responsibilities were not clear". From these statements, periodically reviewing and refining project objectives and responsibilities seems to be worth it, not considering this as static information. In this sense, communication is once again a fundamental practice that needs to be improved. Barnes, Pashby and Gibbons (2006) enhanced also the importance to select, as far as possible, partners that share an strategic interest towards the research, and that are willing and able to fulfill their roles in the project.

The need to sign a formal agreement between the parties was mentioned by all participants, as evidenced by Kerzner (2006). Brocke and Lippe (2015) emphasize that collaborative innovation projects benefit from flexibility in their implementation. However, they also require steadiness and formality (Ruuska \& Teigland, 2009).This practice was highlighted as necessary to formalize the objectives, define responsibilities, establish a work plan, agree on expected results, and indicate the necessary and available resources. This has been referenced in the literature (Barnes et al 2006) as best collaborative project management practices, and was also detected 
among the projects analyzed here. Participants considered it as implicit to what is expected of an effective project. Mentioning agreement terms during the project's opening meeting may be a suitable practice. In project $\mathrm{B}$, a separate contract was entered by and between the university and its partners, since the main contract was signed only by the university and the financing agency, and the complexity of the project called for formalizing the agreement between the parties. "We signed a contract for the partnership, to protect us", said PM2.

The importance of holding an opening meeting was mentioned in three of the four projects analyzed and, although not mentioned by literature, this practice was observed and suggested in the PMBOK (2012). For Project B, the project management department held an opening meeting to share information regarding university processes, to define responsibilities, monitoring tools, among others. "Whenever we start a project [...] the group meets [...]", says the PM2, which complements reporting that "all [project details are] informed in the opening meeting”. The importance of holding an opening meeting for project presentation and eventually signing an opening term was also highlighted by the manager of project $\mathrm{A}$ to emphasize the importance of "reviewing (...) every single event planned for on the project budget"(PM1). In project $\mathrm{D}$, the manager from the university suggests that, in future projects, the practice of holding an opening meeting should be introduced, stating that "it would be interesting to hold a project kickoff meeting with all involved parties in order to define responsibilities and expectations"(PM4).

The need to meet periodically was often mentioned in the form of lack of interaction between partners by participants, including entrepreneurs, researchers and managers. PM3, for example, says that "(...) he (researcher) is working over here (university) and the company staff is there at the company". The entrepreneur and the researcher also agree that there was lack of interaction, reporting that "The execution should have been a bit better, some things were done by the university without our participation. But we also failed by not having a person or a team dedicated to follow [the project]" (B3). R4 corroborates highlighting the that in future projects in would be important to "establish a technical contact person who is more present in the development. Mainly a company employee that could come here every week [...] to monitor the project and assist us on some aspects". Costa, Porto and Feldhaus (2010) point out that a large share of the problems in collaborative projects occur due to the absence of an effective communication, which is also related to ambiguities in the project's initial definitions.
Maintaining personal contact was appointed as essential in this process, as indicated by Jordan et al (2005) and Barnes et al (2006). Project $\mathrm{B}$ manager usually visited his partners without the company of researchers in order to know them better and be an alternative source for information exchange in the course of the activities. "I, as a manager, go there and visit [our partners in the project], so I have another perspective without the researcher, to see if there is a conflict or something else happening [...] I think it works well, and this is a way to [personally] meet the partner. You have to know the outside reality, otherwise it won't work" (PM2). In project A, the entrepreneur confirms the importance of personal contact, stating that "Interpersonal relationship is a very important aspect" (B1). The researcher corroborates with the following information: "We have e-mail, a mentor group e-mail for both mentors and students, we use Google Hangouts to have periodic weekly meetings to check on the project" (R1).They also held weekly meetings for project monitoring with most of the staff, according to the researcher coordinator: "every decision is made at the weekly meeting" (R1). The purpose of the weekly meetings, also according to the researcher, is "to monitor what is happening, so only those who are closely involved participate" (R1). These findings are in accordance to Davenport, Davies and Grimes (1998), since the expectations generated by the collaboration can be very different and effective communication channels become fundamental to project success. In this sense, Costa, Porto and Feldhaus (2010) enhance that conducting personal meetings and fomenting the direct contact among students, scholarship holders, teachers, researchers, technicians, engineers, administrative employees and all persons involved in the collaborative project is very important.

Communicating effectively was one of the most prevalent practices in successful projects. In unsuccessful ones, lack of communication was also greatly mentioned, confirming findings from studies about best practices conducted by Keraminiyage et al. (2009), König et al. (2013), and Brocke and Lippe (2015). This practice was widely highlighted by respondents as an essential factor for successful project management. One of the most important issues in this case concerns access to complete project information. Organizing meetings and writing monitoring reports (Amaral et al 2011) are considered essential for project communication. Aspects such as lack of personal contact, as well as informal processes mostly by e-mail and reports, influenced communication failure, and consequently project monitoring as a whole. R3 comments that "I would point out [the absence of this practice] as the greatest operational failure of all [...] we talk, but do not have a systematic information flow". Management for this same project agrees with the 
researcher, and adds that "the communication was mostly over the Internet, by e-mail, by reports, and little by personal contact. This personal contact is important” (PM3).

Registering project data, which is among the PMBOK (2012) guidelines, is nothing more than a required formality and can be done through documents or software. Most participants highlighted the need for formal information records, which should not be confused with increased bureaucracy. In project $\mathrm{C}$, the entrepreneur highlights the need for greater formalization, commenting that "there was very informal interaction, not that it should be bureaucratized, but I think it has to be a little more formalized [...] for then we might have a history, [because] we have the records" (B3). Recording information is important so there is a history for each project, thus minimizing problems with replacing people, for example, and making it easier for future projects between partners. Also in project $\mathrm{C}$, the manager at the university emphasizes this issue, commenting: "We see the need to formalize and record all project information", says PM3. Since many of the people who were part of the staff are no longer at the university, much of the information was lost, which caused many difficulties for the new team.

Table 7 presents the ten selected best practices, with a brief explanatory description of each practice, their importance for the management of U-I collaborative projects, and a suggested chronology to identify them.

Table 7 - Description and importance of identified best practices

\begin{tabular}{|c|c|c|c|}
\hline Practices & Description & Importance & Chronology \\
\hline $\begin{array}{l}\text { Defining clear } \\
\text { administrative } \\
\text { processes } \\
\text { (University) }\end{array}$ & $\begin{array}{l}\text { Clear and consolidated } \\
\text { processes to guide } \\
\text { management of } \\
\text { collaborative U-I projects } \\
\text { by the university project } \\
\text { management department. }\end{array}$ & $\begin{array}{lrr}\text { Clarifying } & \text { activities } & \text { and } \\
\text { management } & \text { procedures, } \\
\text { facilitating } & \text { activities, } \\
\text { responsibilities, } & \text { and } \\
\text { information flow. } & \end{array}$ & $\begin{array}{l}\text { Before starting the } \\
\text { project }\end{array}$ \\
\hline $\begin{array}{l}\text { Using a project } \\
\text { management } \\
\text { software or } \\
\text { platform }\end{array}$ & $\begin{array}{l}\text { Having a web tool for } \\
\text { recording, optimizing, } \\
\text { and sharing information } \\
\text { related to the project. }\end{array}$ & $\begin{array}{l}\text { Facilitating registration, } \\
\text { consolidation, distribution and } \\
\text { evaluation of the project during } \\
\text { its implementation and after its } \\
\text { closure. }\end{array}$ & $\begin{array}{l}\text { Before starting the } \\
\text { project }\end{array}$ \\
\hline $\begin{array}{l}\text { Setting clear and } \\
\text { realistic goals }\end{array}$ & $\begin{array}{l}\text { Clearly defining project } \\
\text { objectives before the start } \\
\text { and reviewing them } \\
\text { during execution. }\end{array}$ & $\begin{array}{l}\text { Being clear about what will be } \\
\text { done and what is to be achieved. }\end{array}$ & $\begin{array}{l}\text { Before project, with the } \\
\text { possibility of being } \\
\text { revised and improved } \\
\text { during project execution }\end{array}$ \\
\hline $\begin{array}{l}\text { Defini } \\
\text { respons }\end{array}$ & $\begin{array}{l}\text { Clearly defining who does } \\
\text { what in project execution, } \\
\text { especially the firm and the } \\
\text { university. }\end{array}$ & $\begin{array}{l}\text { Being clear about the } \\
\text { responsibility of each person in } \\
\text { the project team, also ensuring } \\
\text { that all institutions involved } \\
\text { contribute and benefit. }\end{array}$ & $\begin{array}{l}\text { Before project, with the } \\
\text { possibility of being } \\
\text { revised and improved } \\
\text { during project execution }\end{array}$ \\
\hline $\begin{array}{l}\text { Signing formal } \\
\text { agreements }\end{array}$ & $\begin{array}{l}\text { Creating clear, simplified } \\
\text { agreements to assist and } \\
\text { facilitate } \\
\text { implementation } \\
\text { projects. }\end{array}$ & $\begin{array}{l}\text { Having a formal document to be } \\
\text { signed by those involved in the } \\
\text { project, aiming to clarify and } \\
\text { ensure the rights and obligations } \\
\text { of partners. }\end{array}$ & $\begin{array}{l}\text { Before project, with the } \\
\text { possibility of being } \\
\text { revised and improved } \\
\text { during project execution }\end{array}$ \\
\hline $\begin{array}{c}\text { Holding an } \\
\text { opening meeting }\end{array}$ & $\begin{array}{l}\text { Holding a project opening } \\
\text { meeting to formalize the } \\
\text { objectives and } \\
\text { responsibilities of the } \\
\text { parties in the project. }\end{array}$ & $\begin{array}{l}\text { Scoring, defining and clarifying } \\
\text { the objectives and } \\
\text { responsibilities of those } \\
\text { involved, allowing for a more } \\
\text { effective implementation. }\end{array}$ & $\begin{array}{l}\text { Before starting the } \\
\text { project }\end{array}$ \\
\hline $\begin{array}{l}\text { Meeting } \\
\text { periodically }\end{array}$ & $\begin{array}{l}\text { Regularly monitoring the } \\
\text { progress of the project, } \\
\text { monitoring the } \\
\text { performance of activities, } \\
\text { and steps. }\end{array}$ & $\begin{array}{l}\text { Enabling monitoring of the } \\
\text { project by those involved as } \\
\text { well as the evaluating activities } \\
\text { and proposing solutions or } \\
\text { possible changes. }\end{array}$ & $\begin{array}{l}\text { During the management } \\
\text { process }\end{array}$ \\
\hline $\begin{array}{l}\text { Maintaining } \\
\text { personal contact }\end{array}$ & $\begin{array}{l}\text { Conducting visits and } \\
\text { regular meetings for } \\
\text { partners, participating in }\end{array}$ & $\begin{array}{l}\text { Promoting personal contact } \\
\text { because it stimulates and } \\
\text { benefits those involved, who }\end{array}$ & $\begin{array}{lc}\text { Before } & \text { starting the } \\
\text { project } & \text { and during } \\
\text { project } & \text { management }\end{array}$ \\
\hline
\end{tabular}




\begin{tabular}{|c|c|c|c|c|}
\hline & $\begin{array}{l}\text { the activities set at each of } \\
\text { the institutions. }\end{array}$ & $\begin{array}{l}\text { can better understand the needs } \\
\text { and limitations of the partners, } \\
\text { and because it can help to } \\
\text { streamline the activities and } \\
\text { solve problems. }\end{array}$ & process & \\
\hline $\begin{array}{l}\text { Communicating } \\
\text { effectively }\end{array}$ & $\begin{array}{l}\text { Keeping those involved } \\
\text { informed on the project. }\end{array}$ & $\begin{array}{l}\text { Creating easy, varied and } \\
\text { accessible communication } \\
\text { channels between partners and } \\
\text { stakeholders of each party } \\
\text { internally, in order to facilitate } \\
\text { project execution. }\end{array}$ & $\begin{array}{l}\text { Before } \\
\text { project } \\
\text { project } \\
\text { process }\end{array}$ & $\begin{array}{l}\text { starting the } \\
\text { and during } \\
\text { management }\end{array}$ \\
\hline $\begin{array}{c}\text { Recording project } \\
\text { data }\end{array}$ & $\begin{array}{l}\text { Recording all information } \\
\text { about the design, } \\
\text { definition, progress, and } \\
\text { project closure. }\end{array}$ & $\begin{array}{l}\text { Recording information makes } \\
\text { communication between } \\
\text { partners easier and enables } \\
\text { those involved to become aware } \\
\text { of the project, including when a } \\
\text { member exits the team. }\end{array}$ & $\begin{array}{l}\text { Before } \\
\text { project } \\
\text { project } \\
\text { process }\end{array}$ & $\begin{array}{l}\text { starting the } \\
\text { and during } \\
\text { management }\end{array}$ \\
\hline
\end{tabular}

Source: Created by the authors (2015)

These proposed best practices may serve as a reference for successful management of U-I collaborative projects. As shown in Table 7, the practices were chronologically classified. However, it is important to note that these practices are not static with respect to the proposed chronology, but dynamically inter-related. For example, periodically monitoring the project through meetings, communication between partners, and personal contact might result in improvement for reconsidering previously determined objectives and responsibilities. Naturally, any amendment should be recorded and formalized, which implies, in many cases, reviewing a project's formal documents, possibly including additive terms to the initial agreement between the parties. In this regard, the project management software or web platform is an important ally, providing those involved with access to project history information, as well as monitoring and reporting performance indicators.

\section{CONCLUSIONS}

The purpose of this study was to identify good managerial practices on university-industry collaborative projects. This study was motivated by the growing number of such projects and the limited number of studies on the subject.

Best management practices were identified from the analysis of successful and unsuccessful projects from the viewpoint of their managers. Practices already found in other studies were confirmed, and new practices were identified. It is important not to understand good project management practices identified in this study as a simple checklist of items to be fulfilled. Best practices should be observed and reviewed repeatedly and progressively from their conception through execution, working as a guide for best practices.

Based on these findings, from a theoretical point of view, this study intends to contribute to the debate on U-I management practices, providing an opportunity to review literature available on the subject, and identify new management practices that influence this process. It is important to note that studies from Davenport et al. (1998), Moro-Valentin et al. (2003), Barnes et al. (2006), and Albertin and Amaral (2010) did not focus exclusively on project management, but on general facilitators and barriers for U-I relations. The practices identified in this study are aligned with the factors identified in previous studies, and provide empirical orientation for the management of U-I collaborative projects, regardless of environmental conditions and preexisting relations.

From a managerial point of view, this study contributes with university project managers, entrepreneurs, and researchers regarding management of U-I collaborative projects. The results provide practical and effective orientation for managing such projects, which therefore develop and consolidate U-I relationships. From the perspective of public management, this study may contribute with development agencies decisions on projects to be selected, given that universities and companies that adopt such practices may have greater chances to optimize available resources and achieve positive results.

Despite its contributions, the study naturally presents limitations, which means that research findings cannot be generalized. The first limitation arises from the fact that some of the projects received external funds and others did not. The usual delay on receiving governmental funds was often mentioned 
as a difficulty for project management, so this may have affected project results more than management or other internal factors. Another important limitation is the wide range of characteristics of firms, universities and researchers participating in the projects. Considering this fact, it is difficult to establish a causal relationship between project management and results.

The weak generalization power of this qualitative study implies that additional studies including a larger number of projects may be conducted to validate the practices presented herein. The public sector may also be included in this analysis, since it usually represents the project funding body, monitors project implementation, and supervises its accountability, therefore directly influencing the way the project is managed. Evaluating the profile and management process offered by universities is also recommended. Finally, it is suggested that some control variables are defined beforehand, such as the characteristics of projects to be analyzed, the corporation's operating area, its proximity to the university, and the presence of funding agencies, since these factors were often mentioned by participants. Finally, some opportunities for further studies do not arise from best practices, but from other factors influencing the development of U-I collaborative projects. Some of these factors include geographical proximity and trust.

\section{ACKNOWLEDGEMENTS}

Universidade Feevale, Brazil

Banco Nacional de Desenvolvimento Econômico e Social (BNDES), Brazil

\section{REFERENCES}

Albertin, E. V., \& Amaral, D. C. (2010) Contexto da parceria como qualificador da gestão de projetos universidade - empresa. Revista Produção, São Paulo, 20(2), 224-236.

Amaral, D. C., Conforto, E.C., Benassi, J. L. G., \& Araújo, C. (2011). Gerenciamento ágil de projetos: aplicação em produtos inovadores. São Paulo: Saraiva.

Ahuja, G. (2000). The Duality of Collaboration: Inducements and Opportunities in the Formation of Interfirm Linkages. Strategic Management Journal, 21(3), 317-343.

Ankrah, S., \& Al-Tabbaa, O. (2015). Universitiesindustry collaboration: a systematic review. Scandinavian Journal of Management, 31(3), 387408.
Bardin, L. (2011). Análise de conteúdo (edição revista e ampliada). São Paulo: Edições 70.

Barnes, T. A., Pashby, I. R., \& Gibbons, A. M. (2006). Managing collaborative R\&D projects development of a practical management tool. International Journal of Project Management, 24(5), 395-404.

Bellucci, A., \& Pennacchio, L. (2015). University knowledge and firm innovation: evidence from European countries. The Journal of Technology Transfer, 40(2), 1-23.

Brocke, J. V., \& Lippe, S. (2015). Managing collaborative research projects: A synthesis of project management literature and directives for future research. International Journal of Project Management, 33(5), 1022-1039.

Burrel, G., \& Morgan, G. (1998). Sociological Paradigms and Organizational Analysis: Elements of the Sociology of Corporate Life. Aldershot, England: Ashgate.

Castells, M. (1999). A sociedade em rede. São Paulo: Paz e Terra.

Costa, P. R., Porto, G. S., \& Feldhaus, D. (2010). Gestão da cooperação empresa universidade: o caso de uma multinacional brasileira. Revista de Administração Contemporânea, 14(1), 100-121.

Davenport, S., Davies, J. D., \& Grimes, C. (1998). Collaborative research programs: building trust from difference. Technovation, 19(1), 31-40.

Ejaz, N., Hussain, J., Shabbir, F., Shamim, M. A., Naeem, U. A., Tahir, M. F., Ahmad, N., \& Farooq, Q.U. (2013). Assessment of most critical success factors for mega construction projects in Pakistan. Life Science Journal, 10(10), 255-261.

Etzkowitz, H. (2009). Hélice Tríplice: UniversidadeIndústria-Governo. Porto Alegre: EDIPUCRS.

Garg, P., \& Agarwal, D. (2014). Critical success factors for ERP implementation in a Fortis hospital: An empirical investigation. Journal of Enterprise Information Management, 27(4), 402-423.

Gulati, R., Lavie, D., \& Madhavan, R. R. (2011). How do networks matter? The performance effects of interorganizational networks. Research in Organizational Behavior, 31, 207-224.

Hagedoorn, J., Link, A., \& Vonortas, N. (2000). Research partnerships, Research Policy, 29 (4), $567-$ 586. 
Hamel, G. (1991). Competition for Competence and Inter-Partner Learning Within International Strategic Alliances. Strategic Management Journal, 12, 83103.

Heravi, G.; \& Ilbeigi, M. (2012). Development of a comprehensive model for construction project success evaluation by contractors. Engineering, Construction and Architectural Management, 19(5), 526-542.

Hwang, B. G., \& Lim, E. S. J. (2013). Critical Success Factors for Key Project Players and Objectives: Case Study of Singapore. Journal of Construction Engineering and Management, 139(2), 204-215.

Johansson, J., \& Kurkkio, M. (2007). Management and evaluation of collaborative R\&D-projects: The paradox of long-term relationships. Nordic Academy of Management, August XX.

Jones, C., \& Lichtenstein, B.B. (2008). Temporary inter-organizational projects: How temporal and social embeddedness enhance coordination and manage uncertainty. In: CROPPER, S. et al. The Oxford handbook of Inter-organizational relations. New York: Oxford University Press.

Jordan, G. B., Hage, J., Mote, J., \& Hepler, B. (2005). Investigating differences among research projects and implications for managers. R\&D Management. 35, 501-511.

Keraminiyage, K. P., Haigh, K.P, \& Amaratunga, R.D.G. (2009). Achieving success in collaborative research: the role of virtual research environments. Journal of Information Technology in Construction (ITCon) 14, 59-69.

Kerzner, H. (2006). Gestão de projetos: as melhores práticas (2a ed.). Porto Alegre: Bookman.

König, B., Diehl, K., Tscherning, K., \& Helming, K. (2013). A framework for structuring interdisciplinary research management. Research Policy 42(1), 261-272.

Lagzian, F., Abrizah, A., \& Wee, M. C. (2013). An identification of a model for digital library critical success factors. The Electronic Library, 31(1), 5-23.

Levine, S. S., \& Prietula, M. J. (2013). Open collaboration for innovation: principles and performance, Organization Science, 25(5), 14141433.

Lynskey, M. J. (1999). The transfer of resources and competencies for developing technological capabilities - The Case of Fujitsu - ICL. Tecnology Analysis \& Strategic Management, 11(3), 317-336.

Moro-Valentin, E. M., Montoro-Sanches, A., \& Guerra-Martin, L. A. (2003). Determining factors in the success of $R \& D$ cooperative agreements between firms and research organizations. Research Policy, 33(1), 17-40.

Mozzato, A. R., \& Grzybovski, D. (2011). Análise de Conteúdo como técnica de análise de dados qualitativos no campo da administração: potencial e desafios. Revista de Administração Contemporânea RAC, 15(4), 731-747.

Nagano, M. S., Stefanovitz, J. P., \& Vick, T. E. (2014). Caracterização de Processos e Desafios de Empresas Industriais Brasileiras na Gestão da Inovação. Revista Brasileira de Gestão e Negócios, 16(51), 163-179.

Pittaway, L., Robertson, M., Munir, K., Denyer, D., \& Neely, A. (2004). Networking and innovation: a systematic review of the evidence. International Journal of Management Reviews, 5/6(3/4), 137-168.

Plonski, G. A. (1994). Academic-Industry Relations in Midle-Income Countries: East Europe and IberoAmerica. Science and Public Policy, 21, 109-116.

Powell, W. W., Kenneth, W. K., \& Doerr, L.S. (1996). Interorganizational Collaboration and the Locus of Innovation: Networks of Learning in Biotechnology. Administrative Science Quarterly, 41(1), 116-145.

Prahalad, C. K., \& Krishnan, M. S. (2008). A Nova era da inovação: A inovação Focada no Relacionamento com o Cliente. Rio de Janeiro: Elsevier.

PMI - Project Management Institute. (2012). Conjunto de Conhecimentos em Gerenciamento de Projetos. [Manual]. Global Standard. Campus Boulevar: Newtown Square. PMI.

Rashvand, P., \& Zaimi, A. M. M. (2014). Critical criteria on client and customer satisfaction for the issue of performance measurement. Journal of Management in Engineering, 10(1), 10 - 18.

Ruuska, I., \& Teigland, R. (2009). Ensuring project success through collective competence and creative conflict in public-private partnerships - a case study of Bygga Villa, a Swedish triple helix egovernment initiative. Int. J. Proj. Manag. 27, 323334. 
Salter, A. J., \& Martin, B. R. (2001). The economic benefits of publicity funded basic research: a critical review. Research Policy, 30, 509-532.
Soda, G. (2011). The management of firms' alliance network positioning: Implications for innovation. European Management Journal, 29, 377 388. 